\title{
The syndrome of isolated epileptic status ${ }^{1}$
}

\author{
J. M. OXBURY AND C. W. M. WHITTY \\ From the Department of Neurology, Radcliffe Infirmary, Oxford
}

SUMMARY Within a group of 23 patients who presented with status epilepticus a syndrome is $\overrightarrow{\overline{\vec{S}}}$ defined in which sudden unheralded status occurs in apparently healthy individuals. Recovery fromo the attack is complete and no other evidence of cerebral pathology may be found at the time. In음 seven of nine such cases studied the final diagnosis at follow-up, either by necropsy or by operation, $\frac{\bar{\rho}}{\frac{5}{5}}$ was of cerebral tumour. In five of the seven the fronto-temporal region was the site of pathology. $\triangle$ It is suggested that the occurrence of isolated status indicates a possible cerebral tumour for whichis careful search should be made and, if negative, follow-up study arranged. Of 20 of our patients withstatus epilepticus in whom the site of lesion was definite, nine were exclusively frontal and a furthersix had some frontal involvement. This confirms previous evidence that symptomatic status $\vec{\omega}$ epilepticus indicates a frontal lesion.

From the records of 2,500 patients with seizures seen in United Oxford Hospitals between 1947 and 1969, we obtained 166 cases of status epilepticus for analysis.

Our definition of status was either that three or more grand mal convulsions occurred without intervening recovery of consciousness, or that there was at least an hour of continuous convulsions without recovery of consciousness. These criteria were rigidly applied, so that we probably excluded some genuine cases of status where the evidence was uncertain.

Of the 166 cases accepted, for reasons concerning investigation and management, we considered further only 96 patients aged 11 years or over. The age incidence is shown in Table 1 . Table 2 shows the probable causes for the condition. The incidence of symptomatic status-about two-thirds of the cases -is relatively high, as is the case in most other series. The high mortality in these symptomatic cases is also noteworthy: including deaths as an immediate result of status, some $50 \%$ of the cases died within six months.

We wish to discuss 23 of the cases who presented with status as their initial symptom. They are divided into two groups. In the first group of 14 cases there was either an already known pathology, or this was established at the time of the occurrence of status. All these cases are therefore examples of symptomatic

'Paper read to the 3rd European Symposium on Epilepsy, Copenhagen, June 1970.
TABLE 1

AGE AT FIRST STATUS EPILEPTICUS

\begin{tabular}{|c|c|}
\hline Years & No. of patients \\
\hline $\begin{array}{r}11-20 \\
21-30 \\
31-40 \\
41-50 \\
51-60 \\
61-70 \\
71-80\end{array}$ & $\begin{array}{r}19 \\
21 \\
15 \\
6 \\
16 \\
15 \\
4\end{array}$ \\
\hline Total & 96 \\
\hline
\end{tabular}

TABLE 2

AETIOLOGY OF STATUS EPILEPTICUS IN 96 CASES AGED 11 TO 80 YEARS

\begin{tabular}{|c|c|}
\hline Pathology & No. of patients \\
\hline Unknown and idiopathic & 32 \\
\hline Trauma & 14 \\
\hline Tumours & 19 \\
\hline Degenerative and arteriosclerotic & 13 \\
\hline Infectious & 9 \\
\hline Congenital and infantile brain lesion & 4 \\
\hline Miscellaneous & 5 \\
\hline Total & 96 \\
\hline
\end{tabular}

status. Table 3 shows the pathological lesion in these cases. In all but one of them it was primarilyos cerebral.

There is a further group of nine cases for which we suggest the term 'lone status epilepticus.' The 
TABLE 3

EPILEPSY PRESENTING AS STATUS OF KNOWN CAUSE

\begin{tabular}{lc}
\hline \multicolumn{1}{c}{ Pathology } & No. of patients \\
\hline Degenerative & 3 \\
Brain scar & 3 \\
Encephalitis & 2 \\
Carcinomatosis & 2 \\
Angioma & 1 \\
Hyponatraemia & 1 \\
Syphilis & 1 \\
Anoxic & 1 \\
$\quad$ Total & 14 \\
\hline
\end{tabular}

main features of this syndrome are: (1) the status presents abruptly in an otherwise healthy adult, (2) there is no past history of any neurological illness, (3) there is complete recovery from the attack, (4) investigations at the time of the attack reveal no causative lesion.

Table 4 shows the age at onset and the investigations carried out. In only one case was there a localized EEG abnormality and, in this case, lumbar puncture and pneumoencephalograms were normal. In two cases the protein was raised and in one of them (case 5) further investigation, which was refused, might have revealed the pathology discovered some six months later. In the other case (case 9), a symmetrical bilateral EEG abnormality led us to postpone further investigation. The patient remained well for 18 months but was then lost to follow-up.

Table 5 shows the subsequent course of the cases and the final diagnosis, achieved either at necropsy or at operation. Further occasional isolated grand mal attacks occurred in three cases, but the emergence of signs of local cerebral disease led to the diagnosis in the majority. Seven of them had proven

TABLE 4

LONE STATUS EPILEPTICUS: INVESTIGATIONS AT TIME OF ATTACK

\begin{tabular}{|c|c|c|c|c|}
\hline $\begin{array}{l}\text { Case } \\
\text { no. }\end{array}$ & $\begin{array}{c}\text { Age at } \\
\text { onset } \\
(y r)\end{array}$ & $E E G$ & $C S F$ & $\begin{array}{c}\text { Angio } \\
\text { or } A E G\end{array}$ \\
\hline 1 & 30 & $\begin{array}{l}\text { Moderate } \\
\text { dysrhythmia }\end{array}$ & Normal & - \\
\hline 2 & 29 & $\begin{array}{l}\text { Moderate } \\
\text { dysrhythmia }\end{array}$ & Normal & Normal \\
\hline 3 & 28 & $\begin{array}{l}\text { Non-focal slow } \\
\text { waves }\end{array}$ & Normal & Normal \\
\hline 4 & 65 & Mild dysrhythmia & Normal & - \\
\hline 5 & 50 & - & $\begin{array}{l}\text { Protein } \\
100 \mathrm{mg}\end{array}$ & - \\
\hline 6 & 53 & $\begin{array}{l}\text { R. frontal spike } \\
\text { focus }\end{array}$ & Normal & Normal \\
\hline 7 & 59 & $\begin{array}{l}\text { Moderate } \\
\text { dysrhythmia }\end{array}$ & 一 & - \\
\hline 8 & 73 & Mild dysrhythmia & Normal & - \\
\hline 9 & 50 & $\begin{array}{l}\text { Bilateral } \\
\text { synchronous } \\
3 \mathrm{~Hz}\end{array}$ & $\begin{array}{l}\text { Protein } \\
80 \mathrm{mg}\end{array}$ & 一 \\
\hline
\end{tabular}

TABLE 5

LONE EPILEPTIC STATUS: AETIOLOGY AND INTERVAL BEFORE DIAGNOSIS

\begin{tabular}{|c|c|c|c|}
\hline $\begin{array}{l}\text { Case } \\
\text { no. }\end{array}$ & Final diagnosis & $\begin{array}{c}\text { Interval } \\
\text { before } \\
\text { diagnosis } \\
(y r)\end{array}$ & Method of diagnosis \\
\hline 1 & L. frontal astrocytoma & 9 & Operation \\
\hline 2 & R. frontal astrocytoma & 5 & Operation \\
\hline 3 & $\begin{array}{l}\text { L. parietal oligodendro- } \\
\text { glioma }\end{array}$ & 5 & Operation \\
\hline 4 & Glioblastoma & 11 & Necropsy \\
\hline 5 & $\begin{array}{l}\text { R. parieto-temporal } \\
\text { astrocytoma }\end{array}$ & $6 / 12$ & Operation \\
\hline 6 & R. frontal glioblastoma & $4 / 12$ & $\begin{array}{l}\text { Operation and } \\
\text { necropsy }\end{array}$ \\
\hline 7 & $\begin{array}{l}\text { L. temporal } \\
\text { glioblastoma }\end{array}$ & $3 / 12$ & Operation \\
\hline 8 & Cerebral atrophy & 9 & Necropsy \\
\hline 9 & Untraced & $?$ & $?$ \\
\hline
\end{tabular}

cerebral tumours. Five of these involved frontal and/or temporal regions. In one, the site was indefinite but described at necropsy as in the anterior part of the hemisphere. The interval from initial status to a verified diagnosis varied from three months to nine years.

Thus we would add a fifth feature to the syndrome: cerebral tumour as its likely cause. The tumours were of varying grades of malignancy; from an oligodendroglioma diagnosed nine years later to a glioblastoma declaring itself in three months. They tended to be anteriorly situated in the hemispheres but were not exclusively so.

Although there are isolated references to sudden status epilepticus as a presenting feature of frontal tumours, we have found no previous description of any group of cases with the picture we have given. In investigating cases of status occurring in nonpenetrating brain injuries, one of us found evidence of frontal lesions in 15 of 17 cases. Janz (1964) also noted that, in a series of cerebral tumours in 27 of which status occurred as part of the symptomatology, 20 or $74 \%$ were frontally situated. Further, in 97 cases of epilepsy from penetrating brain injuries, he also showed that $94 \%$ of those which had status epilepticus had frontal injuries. In this excellent study devoted to status epilepticus and frontal lobe lesions, a number of the cases mentioned would fall into the category we are describing. One of us earlier noted also (Whitty, 1960) that in a series of 356 gunshot wounds of the brain, showing post-traumatic epilepsy, 14 had status as their only form of epilepsy. Twelve of these were frontal wounds.

Pursuing this point in our present status cases, there were 20 patients of the total 96 in whom the site of lesion was definite. The findings are shown in Table 6. Fifty per cent of them were exclusively 
TABLE 6

SITE OF LESION IN 20 CASES OF STATUS EPILEPTICUS

\begin{tabular}{lc}
\hline Site & No. of patients \\
\hline Frontal & 9 \\
Fronto-temporal & 4 \\
Fronto-parieto-temporal & 2 \\
Temporal & 2 \\
Parietal & 3 \\
Total & 20 \\
\hline
\end{tabular}

frontal, and $75 \%$ involved the frontal lobes as well as other areas.

We therefore conclude that:

1. Confirming earlier findings, symptomatic status indicates a frontal lesion. This is both of diagnostie value and of anatomical interest as implying elective pathways of spread of discharge from the frontal lobes.

2. The occurrence of lone status epilepticus indicates the probability of a cerebral tumour and should guide further diagnostic search and influencer prognosis.

3. Status epilepticus-especially symptomatic-i still a serious condition with a high mortality.

\section{REFERENCES}

Janz, D. (1964). Status epilepticus and frontal lobe lesions J. neurol. Sci., 1, 446-457.

Whitty, C. W. M. (1961). Focal epilepsy and the study o cortical function. Med.J. Aust., 1, 1-8.

\section{The February 1971 Issue}

\section{THE FEBRUARY 1971 ISSUE CONTAINS THE FOLLOWING PAPERS}

Geniculate hemianopia: incongruous homonymous field defects in two patients with partial lesions of the lateral geniculate nucleus CARL H. GUNDERSON and WILLIAM F. HOYT

Vasopressin test in cases of optic atrophy and optic neuritis P. O. LUNDBERG, P. O. OSTERMAN, and L. WIDE

Treatment of ocular myasthenia with corticotrophin F. B. GIBBERD, F. NAVAB, and C. L. SMITH

L-Dopa in Parkinsonism associated with cerebellar dysfunction (probable olivopontocerebellar degeneration) HAROLD L. KLAWANS, Jr., and EARL ZEITLIN

Transitory procaine-induced Parkinsonism F. GJERRIS Phosphoribosyl transferase activity in normal subjects, gout patients, and children with mental retardation CHRISTINE EYRE, A. N. DAVISON, and J. T. SCOTT

Linoleate metabolism in multiple sclerosis J. BELIN, $\mathbf{N}$. PETTET, A. D. SMITH, R. H. S. THOMPSON, and K. J. ZILKHA

Urine concentration in depressive illness G. G. ELLIS, ALEC COPPEN, and A. I. M. GLEN

A study of a respiratory related variation of muscle tone during the decrement of decerebrate tonicity in ECT P. C. C. TRESISE

Craniopharyngiomas-a summary of 85 cases J. R. BARTLETT
Neuropathy associated with lymphoma J. C. WALSH

Motor paralysis during asphyxial block of the ulnar negिve D. C. SINCLAIR, A. B. MATHESON, and W. G. SKENE

Observations on the responses of muscle to mechanfar and electrical stimuli J. C. MEADOws

Diagnosis and treatment of thoracic intervertebral dise protrusions JAMES CARSON, JOHN GUMPERT, and ANTONY JEFFERSON

Observations on distal intravascular pressure change and cerebral blood flow after common carotid artery ligation in man A. E. HOLMES, I. M. JAMES, and C. C. WIS Posterior fossa subdural haematoma associated with anticoagulant therapy T. CAPISTRANT, R. GOLDBERG, $\mathrm{H}$ SHIBASAKI, and D. CASTLE

Reappraisal of alcoholic myopathy AMIN A. FARIS an MARCELINO G. REYES

Familial muscular dystrophy of late onset PAUL A BACON and BARBARA SMITH

Epilepsy after missile wounds of the head ADELOLA ADELOYE and E. LATUNDE ODEKU

Proceedings of the Society of British NeurologicaP Surgeons

Book reviews

Copies are still available from the PUBLISHING MANAGER BRITISH MEDICAL ASSOCIATION, TAVISTOCK SQUARE, LONDON, WC1H 9JR, price $£ 1 \cdot 50$ 